\title{
Mantle plume and island arc lithosphere prints in Cambrian granitoids and mafic rocks from the Kuznetsk Alatau Orogen, Siberia
}

\author{
V.V. VRublevskiI ${ }^{1}$, A.D. Kotelnikov ${ }^{1}$ \\ ${ }^{1}$ Tomsk State University, Tomsk, 634050, Russia \\ (vasvr@yandex.ru)
}

The Cambrian (510-490 Ma) granitoids, gabbromonzonite and alkaline-mafic plutons are localized of the Kuznetsk Alatau accretionary-collisional orogen, which is involved in the western Central Asian fold belt. The igneous rocks have $\mathrm{K}-\mathrm{Na}$ alkalinity and similar trace element and $\mathrm{Nd}-\mathrm{Sr}$ isotope geochemistry. They are characterized by the enrichment of LILE and partly Th, U, La and Ce relative to OIB-like "intraplate" source, but general HFSE spectra most correspond to the distribution of IAB-"subduction"source with typical $\mathrm{Nb}-\mathrm{Ta}$ and $\mathrm{Zr}$-Hf minima. This suggests a mixing of rock material from an earlier island arc with a mantle plume.

The observed wide range of $\varepsilon_{\mathrm{Nd}}(\mathrm{t})$ from 8.7 to 2 in rocks may be due to the interaction scale of depleted PREMA-like and enriched lithospheric mantle (EM-type) components by the parent melts generation. Probably the amount of EMcomponents is increased in magma sources of gabbromonzonite and granitoid series [1,2]. On the other hand, igneous rocks have increased isotope ratios of ${ }^{87} \mathrm{Sr} /{ }^{86} \mathrm{Sr}(\mathrm{t})$ $0.7039-0.7058$ and $\delta^{18} \mathrm{O}$ to $7-13 \%$ that are usually associated with crustal contamination of melts.

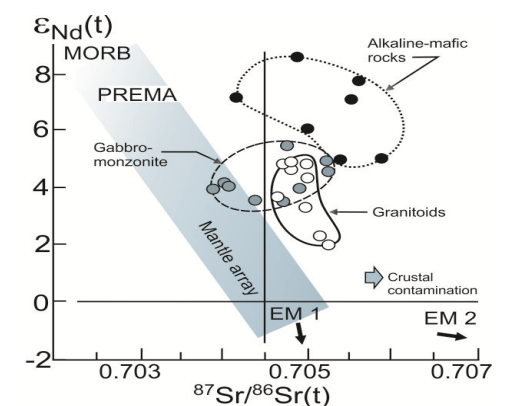

Geochemical peculiarities and convergency of the Cambrian magmatic derivatives in the Kuznetsk Alatau assume their complex tectonic setting when a mantle plume interacted with earlier active margin lithosphere of the Paleo-Asian Ocean. The study was supported by the Russian Science Foundation (project no 18-17-00240).

[1] Vrublevskii et al. (2016) Rus Geol Geophys 57, 225246. [2] Vrublevskii et al. (2018) Rus Geol Geophys 59, 718-744. 